\title{
A JUSTIFICAÇÃO CONSTITUCIONAL DA EXECUÇÃO PROVISÓRIA DA PENA PRIVATIVA DE LIBERDADE NA PENDÊNCIA DOS RECURSOS EXTRAORDINÁRIO E ESPECIAL RECEBIDOS SEM EFEITO SUSPENSIVO
}

\author{
THE CONSTITUTIONAL JUSTIFICATION OF THE PROVISIONAL EXECUTION OF \\ THE SENTENCE OF IMPRISONMENT PENDING EXTRAORDINARY AND SPECIAL \\ RECOURSES RECEIVED WITHOUT SUSPENSIVE EFFECT
}

\author{
Rafael Schwez Kurkowski \\ Mestrando pelo UNICEUB. Especialista em Gestão Acadêmica do Ensino Superior pela \\ Faculdade Pio Décimo. Membro do Ministério Público do Estado de Sergipe. \\ E-mail: rafadir2000@yahoo.com.br
}

Recebido em: 15/11/2016

Aprovado em: 03/05/2017

Doi: $10.5585 / \mathrm{rdb} . v 18 \mathrm{i} 7.504$

RESUMO: O presente artigo demonstra que a execução provisória da pena privativa de liberdade na pendência de recurso extraordinário e/ou especial recebido sem efeito suspensivo tem justificação na Constituição Federal, cuja interpretação sistemática deve primar pela sua unidade. A execução provisória, que respeita os direitos fundamentais relacionados ao status libertatis do réu e aqueles alusivos ao processo judicial, resulta da harmonização obtida pela proporcionalidade, vista como proibição de insuficiência, entre a presunção de inocência do réu, cuja culpabilidade não mais comporta discussão, e a segurança pública, a qual deve ser buscada pelo Estado, incluindo o Poder Judiciário. A revisão bibliográfica e a análise da jurisprudência do Supremo Tribunal Federal revelam que a execução provisória da pena é plenamente compatível com a Constituição Federal, especialmente com o princípio da presunção de inocência.

Palavras-chave: Pena. Execução Provisória. Interpretação constitucional. Proporcionalidade.

ABSTRACT: The present article demonstrates that the provisional execution of the sentence of imprisonment pending extraordinary and/or special recourse received without suspensive effect is justified in the Constitution, whose systematic interpretation should strive for its unity. Provisional execution, that respects the fundamental rights related to the defendant status libertatis and those allusive to judicial proceeding, resultes from the harmonization achieved by proportionality, seen as prohibiton of insuficiency, between the defendant's presumption of innocence, whose guilt no longer holds discussion, and the public security, which must be pursued by the state, including the Judiciary. The literature review and analysis of the jurisprudence of the Supreme Court reveals that the provisional execution of the sentence is fully compatible with the Constitution, especially with the principle of presumption of innocence.

Keywords: Sentence. Provisional execution. Constitutional interpretation. Proportionality.

SUMÁRIO: Introdução. 1 Direitos fundamentais permissivos da execução provisória da pena privativa de liberdade após o encerramento das instâncias ordinárias. $1.1 \mathrm{O}$ respeito pela execução provisória da pena a direitos fundamentais relacionados ao processo criminal. 1.1.1 Duplo grau de jurisdição: exigência de julgamento por órgão colegiado. 1.1.2 Ampla defesa: a 
defesa técnica persiste atuando após a sentença condenatória. 1.1.3 Contraditório: bilateralidade do ato processo permanece garantida ao réu. 1.1.4 Devido processo legal: proporcionalidade da restrição ao direito de liberdade. 1.1.5 Presunção de não-culpabilidade: princípio relacionado ao ônus da prova de que já se desincumbiu o ministério público. 1.2 Segurança pública: instituto a ser observado em todo o processo criminal. 2 Execução provisória da pena: resultado da harmonização da presunção de inocência com a segurança pública. 2.1 Definição da culpa é anterior ao julgamento dos recursos excepcionais. 2.2 Existência de meios para combater eventual ilegalidade na execução provisória. 2.3 A interpretação constitucional direcionada à realização da segurança pública. 2.3.1 Inexistência de valor absoluto nos princípios: seu caráter prima facie. 2.3.2 A interpretação sistemática visa à unidade da constituição federal. 2.3.3 A vinculação do poder judiciário à realização da segurança pública. $2.4 \mathrm{O}$ enaltecimento conferido pela proporcionalidade, como proibição contra a proteção insuficiente, à segurança pública na execução provisória da pena. Conclusão. Referências Bibliográficas.

\section{INTRODUÇÃO}

No hábeas-córpus ${ }^{1} \mathrm{n}^{\circ}$. 84.078-7/MG, julgado em 2009, o Supremo Tribunal Federal (STF), por maioria, contrariando a jurisprudência até então dominante, decidiu no sentido da inconstitucionalidade da execução antecipada (rectius: provisória) da pena, sob dois principais argumentos: a presunção de não-culpabilidade exigiria, à exceção da prisão cautelar, o trânsito em julgado da sentença condenatória; e a ampla defesa incidiria, sem qualquer tipo de gradação, durante todas as fases do processo penal. O processo criminal em questão referia-se a uma condenação do réu a 7 anos e 6 meses de reclusão pela prática do crime tipificado no art. $121, \S$ $2^{\circ}$, I e IV, do CP.

Por sua vez, em sentido diametralmente oposto, no julgamento do $\mathrm{HC} \mathrm{n}^{\circ}$. 126.292/SP, o mesmo STF, em fevereiro de 2016, revigorando a jurisprudência anterior ao $\mathrm{HC} \mathrm{n}^{\circ}$. 84.078$7 / \mathrm{MG}^{2}{ }^{3}$, decidiu, por maioria, no sentido da constitucionalidade da execução provisória da pena privativa de liberdade, sob o principal argumento de que ela "não compromete o princípio constitucional da presunção de inocência afirmado pelo artigo $5^{\circ}$, inciso LVII da Constituição Federal". O caso concreto referia-se a um réu que fora condenado a 5 anos e 4 meses de reclusão pela prática do crime tipificado no art. $157, \S 2^{\circ}$, I e II, do CP.

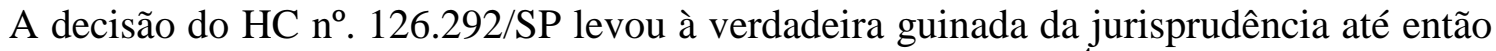
orientada pelo modelo de entendimento previsto no $\mathrm{HC} \mathrm{n}^{\circ} .84 .087-7 / \mathrm{MG}^{4}$.

\footnotetext{
${ }^{1}$ Sobre a forma hábeas-córpus, Kaspary ensina: "Hábeas-córpus é a forma lógica e completamente aportuguesada: com hífen, para indicar a unidade semântica do termo (à semelhança de pena-base, dias-multa, queixa-crime, etc.); com acento gráfico em hábeas, por ser paroxítona terminada em ditongo crescente (à semelhança de pâncreas, várzea, área, etc.); e também com acento gráfico em córpus, por ser paroxítona terminada em us (à semelhança de vírus, húmus, Vênus, etc.). Compare-se o termo com outros latinismos aportuguesados, tais como mapa-múndi, vade-mécum, pró-forma, fac-símile, etc.” (KASPARY, Adalberto J. Habeas Verba: português para juristas. $8^{\mathrm{a}}$ ed. Porto Alegre: Ed. Livraria dos Advogados, 2005.)

${ }^{2}$ Por exemplo: BRASIL, Supremo Tribunal Federal. Hábeas-córpus nº ${ }^{\circ}$ HC 68726, Relator(a): Min. Néri da Silveira.

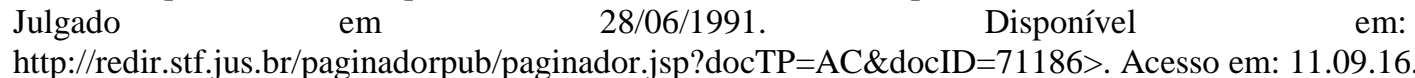

http://redir.stf.jus.br/paginadorpub/paginador.jsp?docTP=AC\&docID=71186>. Acesso em: 11.09 .16 .
${ }^{3}$ Além disso, a inteligência dos verbetes números 716 e 717 da Súmula do STF aponta para a aceitação da execução provisória da pena. Diz a Súmula $\mathrm{n}^{\circ}$. 716: "Admite-se a progressão de regime de cumprimento da pena ou a aplicação imediata de regime menos severo nela determinada, antes do trânsito em julgado da sentença condenatória". Já a Súmula nº. 717: "Não impede a progressão de regime de execução da pena, fixada em sentença não transitada em julgado, o fato de o réu se encontrar em prisão especial".

${ }^{4}$ Confira-se o seguinte exemplo de aresto que seguiu o entendimento esposado no $\mathrm{HC} \mathrm{n}^{\circ}$. 126.292/SP, no sentido da constitucionalidade da execução provisória da pena: BRASIL, Supremo Tribunal Federal, agravo regimento $\mathrm{n}^{\circ}$. 737305 AgR, Relator(a): Min. GILMAR MENDES, Segunda Turma, julgado em 28/06/2016,. Disponível em: <http://redir.stf.jus.br/paginadorpub/paginador.jsp?docTP=TP\&docID=11479231>. Acesso em: 14.09.16.
}

Revista de Direito Brasileira | São Paulo, SP | v. 18 | n. 7 | p. 242 - 262 |Set./Dez. 2017 
Posteriormente, em outubro de 2016, o STF indeferiu a medida cautelar postulada nas Ações Declaratórias de Constitucionalidade números 43 e 44, cujo objeto versava sobre o art. 283 do CPP. A despeito de o acórdão não haver sido publicado na data de fechamento deste artigo, notícia veiculada no site do STF informou que a maioria dos Ministros considerou que o art. 283 do CPP "não impede o início da execução da pena após condenação em segunda instância"5.

Fundamentalmente, a divergência reside quanto à (des)necessidade do trânsito em julgado da sentença penal condenatória para o início do cumprimento da pena privativa de liberdade.

A evolução retratada nesse quadro decisório revigorou o interesse no estudo sobre a possibilidade da execução provisória da pena privativa de liberdade, na pendência dos recursos extraordinário (art. 102, III, da CRFB) e especial (art. 105, III, da CRFB) recebidos sem efeito suspensivo. Além da entrada em vigor do Novo Código de Processo Civil - NCPC (Lei $n^{\circ}$. 13.105/15), que prevê a atribuição de efeito suspensivo a esses dois tipos de recursos, fundamentos que não foram explorados pelo STF justificam o presente estudo.

A rigor, trata-se de execução "provisória" - e não "antecipada", como constou nos votos contrários à execução provisória da pena constantes do $\mathrm{HC} \mathrm{n}$. 84.078-7/MG -, porquanto a execução deixa de existir uma vez desaparecidos os seus pressupostos. O Dicionário Houaiss ${ }^{6}$ registra "antecipado" como um adjetivo que exprime a ideia de "feito ou ocorrido antes do tempo próprio ou necessário; adiantado, precoce, prévio"; já o adjetivo "provisório" designa algo que "que não tem caráter de permanente; temporário, provisional". Assim, "antecipado" consiste em algo que tem caráter de permanente, embora tenha sucedido antes do seu tempo. Na medida em que o Direito envolve linguagem, percebe-se que a execução "provisória" da pena foi tratada, capciosamente, como execução "antecipada" pelo $\mathrm{HC} \mathrm{n}$. 84.078-7/MG, especialmente para justificar a sua inconstitucionalidade. De fato, a execução "antecipada" da pena privativa de liberdade é flagrantemente inconstitucional, na medida em que envolve o cumprimento definitivo de um título condenatório que ainda não existe.

A execução provisória ora tratada envolve o esgotamento das instâncias ordinárias na Justiça Comum Criminal Federal e Estadual, vale dizer, quando já ocorreu o pronunciamento definitivo dos Tribunais de Justiça dos Estados e dos Tribunais Regionais Federais sobre o mérito da ação penal. Tal sucede com o julgamento dos recursos de apelação (art. 593 do CPP), de embargos infringentes e/ou de nulidade (art. 609, parágrafo único, do CPP) e dos eventuais embargos de declaração (art. 619 do CPP) interpostos.

$\mathrm{Na}$ execução provisória da pena privativa de liberdade, que respeita princípios fundamentais relacionados ao processo judicial e ao status libertatis, verifica-se a colisão do princípio da presunção de não-culpabilidade ${ }^{7}$, que traduz regra disciplinadora do ônus da prova, com a segurança pública, a qual - constituindo parâmetro de integração e de interpretação, objetivo da República, direito fundamental individual, direito social fundamental e dever do Estado - deve ser garantida pelo Estado, por intermédio dos seus três Poderes, entre os quais figura o Judiciário. Tal colisão, observado o caráter prima facie dos princípios, pelo qual eles são aplicados de forma gradativa, ou seja, na medida das possibilidades jurídicas e fáticas, é resolvida por meio do sopesamento entre eles. Este é realizado por intermédio da proporcionalidade. Contudo, aqui não se cuida da proporcionalidade como a clássica "proibição de excesso" (de cunho negativo, visando à abstenção do Estado), mas como "proibição de insuficiência", "momento em que a preocupação do sistema jurídico será com o fato de o Estado não proteger

\footnotetext{
${ }^{5}$ Disponível em: <http://www.stf.jus.br/portal/cms/verNoticiaDetalhe.asp?idConteudo=326754>. Acesso em: 10 out 2016.

${ }^{6}$ HOUAISS, Antônio. Dicionário Eletrônico 3.0. Versão eletrônica. Ed. Objetiva, 2009.

${ }^{7}$ Este trabalho segue a linha doutrinária, a exemplo de Nucci, que considera presunção de não-culpabilidade e presunção de inocência sinônimos. (NUCCI, Guilherme de Souza. Código de processo penal comentado. $5^{\text {a }}$. ed. São Paulo: Ed. Revista dos Tribunais, 2006. p. 53.)
}

Revista de Direito Brasileira | São Paulo, SP | v. 18 | n. 7 | p. 242 - 262 | Set./Dez. 2017 
suficientemente determinado direito fundamental" ${ }^{\text {. }}$. Nessa operação, impõe-se também o respeito aos postulados da concordância prática, o qual objetiva a realização máxima dos princípios tensionados, não obstante procure o equilíbrio entre eles, e da proibição do excesso, visto agora como preservação do núcleo essencial, que proíbe a restrição excessiva de qualquer direito fundamental ${ }^{9}$.

É digno observar também que, na ordem internacional, o trânsito em julgado da sentença penal condenatória não é exigido para o início do cumprimento da pena privativa de liberdade, conforme se depreende da leitura do art. 11, item 1, da Declaração Universal dos Direitos do Homem, e do art. $7^{\circ}$, item 2, da Convenção Americana de Direitos Humanos. Tais dispositivos legais, destacando-se que o primeiro diploma, a despeito de não ter valor vinculante, representa o ideal a ser perseguido pelos países que prezam pelos direitos humanos, condicionam a presunção de inocência e a prisão, respectivamente, à demonstração da culpabilidade em processo judicial, e não ao trânsito em julgado da sentença condenatória. No processo judicial brasileiro, a culpabilidade $^{10}$ é evidenciada justamente com o encerramento das instâncias ordinárias, em função da impossibilidade de discussão posterior sobre ela. Porque a culpabilidade respeita ao fato e porque os recursos excepcionais - extraordinário e especial - versam apenas sobre a legislação abstrata, não há lugar para discutir a culpabilidade na instância especial, o que consolida o seu reconhecimento na instância ordinária. Pode-se, assim, cogitar da coisa julgada quanto ao capítulo sentencial da culpabilidade.

Como o tema envolve sobremaneira direitos fundamentais e princípios de estatura constitucional, este artigo levará em conta principalmente a jurisprudência do STF em razão de ele ter a última palavra sobre ela. Especialmente, será conferido enfoque ao HC no. 126.292-SP, porquanto, em se tratando de caso paradigmático, mesmo que não haja eficácia vinculante, $\mathrm{o}$ "STF ao julgar uma controvérsia não decide apenas um caso posto ao seu crivo, mas indica a direção normativa que devem seguir os indivíduos (e as autoridades) e as instituições (públicas ou particulares)"11.

A conformação constitucional da segurança pública justifica a execução provisória da pena privativa de liberdade após o encerramento das instâncias ordinárias. As pesquisas doutrinária, jurisprudencial e legal nacional e estrangeira aliadas à dialética que se estabelecerá entre o $\mathrm{HC} \mathrm{n}^{\circ}$. 84.078-7/MG e o $\mathrm{HC} \mathrm{n}^{\circ}$. 126.292/SP demonstrarão: a) a Constituição Federal vincula o Poder Judiciário, nas suas decisões, à realização da segurança pública; b) o ordenamento jurídico pátrio confere meios adequados para discutir eventual ilegalidade da execução provisória da pena privativa de liberdade, quais sejam, o hábeas-córpus e a possibilidade de agregação do efeito suspensivo aos recursos extraordinário e especial; e c) uma interpretação sistemática da Constituição Federal, com amparo na proporcionalidade vista como proibição de insuficiência, revela que a execução provisória da pena privativa de liberdade é providência comum e esperada após o encerramento da instância ordinária, visto que a culpabilidade do réu já foi demonstrada, não obstante lhe continue facultada toda a oportunidade de sua (ampla) defesa.

\footnotetext{
${ }^{8}$ STRECK, Lênio Luiz. A dupla face do princípio da proporcionalidade: da proibição de excesso (Übermassverbot) à proibição de proteção deficiente (Untermassverbot) ou de como não há blindagem contra normas penais inconstitucionais. Revista da Ajuris, ano XXXII, nº. 97, março de 2005. p. 179.

9 ÁVILA, Humberto. Teoria dos Princípios da definição à aplicação dos princípios jurídicos. $4^{\mathrm{a}} \mathrm{Ed}$. Ed. Malheiros, 2004. p. 96-97.

${ }^{10}$ Referindo-se à reprovação social incidente sobre uma conduta típica que apresenta um nexo causal com um resultado lesivo, o presente trabalho emprega os vocábulos "culpa" e "culpabilidade" como sinônimas, na linha da doutrina de Francisco de Assis Toledo. (TOLEDO, Francisco de Assis. Princípios básicos de direito penal. $5^{\mathrm{a}}$ ed. São Paulo: Ed. Saraiva, 1994. p. 216)

${ }^{11}$ ALVES JR., Luís Carlos Martins. Constituição, Política \& Retórica. Brasília: Uniceub, 2014. p. 108.
} Revista de Direito Brasileira | São Paulo, SP | v. 18 | n. 7 | p. 242 - 262 |Set./Dez. 2017 


\section{DIREITOS FUNDAMENTAIS PERMISSIVOS DA EXECUÇÃO PROVISÓRIA DA PENA PRIVATIVA DE LIBERDADE APÓS O ENCERRAMENTO DAS INSTÂNCIAS ORDINÁRIAS}

Por ser tipicamente um hard case ${ }^{12}$, a execução provisória da pena privativa de liberdade na pendência de recursos extraordinário e especial aos quais não foi atribuído efeito suspensivo envolve o estudo de princípios constitucionais.

No HC n ${ }^{\circ}$. 84.078-7/MG bem como em certa doutrina ${ }^{13}$, sustenta-se que a execução provisória da pena viola os seguintes princípios: duplo grau de jurisdição, ampla defesa, contraditório, devido processo legal e presunção de inocência.

Analisa-se, doravante, a influência da execução provisória da pena sobre tais princípios, os quais constituem verdadeiros direitos fundamentais ${ }^{14}$, com a peculiaridade logo abaixo tecida quanto ao duplo grau de jurisdição. A análise será dividida em duas seções: na primeira, serão estudados os princípios fundamentais que se relacionam intimamente com o processo judicial e o status libertatis; na segunda, será perquirida a segurança pública, em todas as suas feições.

\subsection{0 respeito pela execução provisória da pena a direitos fundamentais relacionados ao processo criminal}

\subsubsection{Duplo grau de jurisdição: exigência de julgamento por órgão colegiado}

Ensina-se que o duplo grau de jurisdição assegura a revisão da matéria fática, além da de direito, por um órgão hierarquicamente superior ao prolator da decisão ${ }^{15}$. O STF entende que tal princípio não é absoluto, comportando exceções, dadas as hipóteses de ações penais originárias, nas quais sucede o julgamento em única instância ${ }^{16}$. São as hipóteses previstas no art. 102, I, $b$ e $c$, da CF. Assim, "há competências originárias em que não haverá o chamado duplo grau de jurisdição, por exemplo, nas ações de competência originária dos Tribunais" ${ }^{17}$. Tal ocorre porque esses recursos não examinam a matéria de fato que subjaz a demanda.

De toda sorte, o duplo grau de jurisdição foi adequadamente analisado por FISCHER, no sentido de que o princípio em tela apenas assegura um julgamento por órgão colegiado, seja originariamente, seja em grau recursal. O objetivo consiste em evitar os riscos de injustiças

\footnotetext{
${ }^{12}$ A expressão hard case "identifica as situações para as quais não há formulação simples e objetiva a ser colhida no ordenamento, sendo necessária a atuação subjetiva do intérprete e a realização de escolhas, com eventual emprego de discricionariedade" (BARROSO, Luís Roberto. BARCELLOS, Ana Paula. O começo da história. A nova interpretação constitucional e o papel dos princípios no direito brasileiro. O Interesse Público IP. Belo Horizonte, $\mathrm{n}^{\circ}$. 19, ano 5 Maio / Junho 2003 Disponível em: <http://www.bidforum.com.br/bid/PDI0006.aspx?pdiCntd=50962>. Acesso em: 04.05.2016).

${ }^{13}$ É a posição de Pacelli, por exemplo. (OLIVEIRA, Eugênio Pacelli. FISCHER, Douglas. Comentários ao Código de Processo Penal e sua jurisprudência. $4^{\mathrm{a}}$ ed. São Paulo: Ed. Atlas, 2012. p. 552)

${ }^{14}$ Observando o seu caráter prima facie, que será estudado mais abaixo, PULIDO afirma que os "direitos fundamentais são o exemplo mais claro de princípios que temos no ordenamento jurídico" (PULIDO, Carlos Bernal. O direito dos direitos: escritos sobre a aplicação dos direitos fundamentais. Tradução: Thomas da Rosa de Bustamante. São Paulo: Ed. Marcial Pons, 2013. p. 93).

${ }^{15}$ GRINOVER, Ada Pellegrini. GOMES FILHO, Antônio Magalhães. FERNANDES, Antônio Scarance. Recursos no processo penal: teoria geral dos recursos, recursos em espécie, ações de impugnação, reclamação aos tribunais. $6^{a}$ ed. São Paulo: Ed. RT, 2009. p. 23.

${ }^{16}$ Nesse sentido, confiram-se os seguintes julgados: BRASIL, Supremo Tribunal Federal, RHC 79785, Relator(a): Min. SEPÚlVEDA PERTENCE, Tribunal Pleno, julgado em 29/03/2000. Disponível em: <79785>. Acesso em: 14.09.16.; e BRASIL, Supremo Tribunal Federal, AI 601832 AgR, Relator(a): Min. JOAQUIM BARBOSA, Segunda Turma, julgado em 17/03/2009. Disponível em: <http://redir.stf.jus.br/paginadorpub/paginador.jsp?docTP=AC\&docID=584974>. Acesso em: 14.09.16.

${ }^{17}$ MORAES, Alexandre de. Direito Constitucional. $20^{\mathrm{a}}$ ed. São Paulo: Ed. Atlas, 2006. p. 73.
} 
decorrentes de decisão exarada por um juízo monocrático, que, justamente por decidir sozinho, estaria sujeito a uma probabilidade maior de cometimento de erros. ${ }^{18}$

Tal conceituação permite entrever o duplo grau de jurisdição mesmo nas ações penais que envolvem prerrogativa de foro no STF, já que, apesar da instância única, o julgamento é realizado por um órgão colegiado. Além disso, ela explica satisfatoriamente a restrição recursal na apelação interposta em sede de júri, a qual tem severa limitação quanto aos fatos, já que, neste caso, apenas pode versar sobre um veredicto manifestamente contrário à prova dos autos (art. 593, III, $d$, do CPP). E não se admite a interposição de nova apelação pelo mesmo fundamento, seja pela acusação, seja pela defesa (art. 593, § $3^{\circ}$, do CPP). Ora, se não houver decisão manifestamente contrária à prova dos autos, a decisão quanto ao fato (repisa-se que a culpabilidade constitui matéria de fato), apesar de haver sido tomada por um órgão judiciário de primeiro grau - mas colegiado -, é irrevisável. Tal exceção cabal ao princípio do duplo grau de jurisdição passou despercebida pela doutrina e é satisfatoriamente explicada pelo conceito do princípio em tela, que se contenta por um julgamento por órgão colegiado.

Frisa-se que a interposição de recurso extraordinário e/ou especial evidencia que um órgão colegiado já apreciou - e esgotou - o fato sob seu julgamento, o que demonstra a inexistência de ofensa ao princípio em questão pela execução provisória.

\subsubsection{Ampla defesa: a defesa técnica persiste atuando após a sentença condenatória}

A ampla defesa (art. 5\% LV, da CF) é assegurada mediante o exercício da autodefesa, que é renunciável, e da defesa técnica, a qual é irrenunciável. Aquela tem lugar, por excelência, no primeiro grau de jurisdição (ou no grau originário), pois é exercida mediante o direito de presença - acompanhamento de toda a instrução probatória - e o direito de audiência - direito de ser ouvido pelo julgador, o que ocorre no interrogatório. A defesa técnica, por sua vez, é garantida mediante o patrocínio por advogado, a qual se justifica na presunção de hipossuficiência jurídica do sujeito passivo para resistir à pretensão estatal, em igualdade de condições técnicas com o acusador ${ }^{19}$. A defesa técnica tem lugar durante todo o processo de conhecimento, avançando inclusive para o de execução, dada a imprescindibilidade da presença do advogado para a prática de qualquer ato de que possa resultar prejuízo ao réu.

Por conseguinte, considerando que o réu continua tendo a sua (ampla) defesa garantida por advogado na hipótese de interposição de recurso(s) excepcional(is), a execução provisória não implica nenhuma ofensa ao princípio da ampla defesa.

\subsubsection{Contraditório: bilateralidade do ato processo permanece garantida ao réu}

O contraditório representa a bilateralidade do ato processual. Assegurando-se condições de igualdade à acusação e à defesa, o processo judicial confere iguais chances a eles para permitir "a contribuição das partes para a formação do convencimento do juiz e, assim, para o provimento final almejado" 20 . Para tanto, as partes devem ser informadas acerca dos atos processuais.

Sob a óptica da defesa, esta é intimada previamente sobre a decisão que encerra a instância ordinária (hipóteses mais comuns: apelação ou embargos infringentes e/ou de nulidade). Logo, se houver a ordem de prisão, abrem-se à defesa, em razão da sua intimação prévia, ferramentas para combater o mandado de prisão ilegal, quais sejam: agregação do efeito suspensivo aos recursos extraordinário e especial e impetração de hábeas-córpus.

\footnotetext{
18 FISCHER, Douglas. Execução de Pena na Pendência de Recursos Extraordinário e Especial em Face da Interpretação Sistêmica da Constituição. Uma Análise do Princípio da Proporcionalidade: entre a Proibição do Excesso e a Proibição de Proteção Deficiente in Direito Público. Ano V, no. 25, jan-fev 2009. p. 16.

${ }^{19}$ LOPES JR., Aury. Direito Processual Penal. $9^{a}$ ed. São Paulo: Saraiva, 2012. p. 243.

${ }^{20}$ OLIVEIRA, Eugênio Pacelli. Curso de Processo Penal. 12 ${ }^{\mathrm{a}}$ ed. Rio de Janeiro: Lumen Iuris, 2009. p. 38.
} Revista de Direito Brasileira | São Paulo, SP | v. 18 | n. 7 | p. 242 - 262 |Set./Dez. 2017 
Tendo em vista, dessa forma, a informação prévia sobre a ordem de prisão, mediante a intimação da defesa técnica, e a existência de ferramentas hábeis e céleres para combatê-la, não se divisa qualquer mácula ao princípio do contraditório provocada pela execução provisória da pena.

\subsubsection{Devido processo legal: proporcionalidade da restrição ao direito de liberdade}

O devido processo legal "processual" implica a observância de um procedimento previamente estabelecido em lei para que o processo judicial chegue ao seu termo.

Já pelo devido processo legal "substantivo", o STF tem apreciado a proporcionalidade e a razoabilidade de todos os atos normativos submetidos ao seu crivo. Ou seja, toda e qualquer norma jurídica poderá ter sindicada a sua validade constitucional se acusada de violação aos princípios da proporcionalidade e da razoabilidade (ou do devido processo legal substantivo) ${ }^{21}$.

Logo, além de o procedimento estar simplesmente previsto em lei, é necessário que ele atenda aos ditames da proporcionalidade.

De outra banda, o ex-Ministro do STF Cesar Peluso, no seu voto no julgamento do HC $n^{\circ}$. 84078-7/MG, contrário à execução provisória da pena, registrou que o devido processo legal, na acepção norte-americana do due process of law, compreenderia um apelo para os ideais de justiça. Em seguida, na sua visão, um processo que permitisse a execução provisória da pena, sem juízo definitivo de condenação e sem reconhecimento definitivo de culpa, poderia ser um processo legal, mas não justo, e, por isso mesmo, não seria um processo que atendesse ao princípio constitucional em comento ${ }^{22}$. Ocorre que, com a vênia do ex-Ministro, se já se pode falar em reconhecimento definitivo da culpabilidade, após a preclusão da matéria fática - e a culpabilidade diz respeito a fato, não à lei em tese - havida com o encerramento da instância ordinária, é necessário analisar se a execução provisória da pena, justificada pela segurança, é justa. Adianta-se que ela o é, conforme análise que será realizada mais abaixo.

\subsubsection{Presunção de não-culpabilidade: princípio relacionado ao ônus da prova de que já se desincumbiu o Ministério Público}

Positivada no art. 5, LVII, da CF, a famigerada presunção de não-culpabilidade ou de inocência consiste em regra de tratamento ligada ao ônus da prova, e não em regra de direito material. Ela simplesmente impõe todo o ônus da prova quanto à materialidade e à autoria do crime ao acusador. Segundo Nucci: "O princípio tem por objetivo garantir que o ônus da prova cabe à acusação e não à defesa" ${ }^{\text {23 }}$.

Da presunção sob exame, origina-se o nemu tenetur se detegere, pois o agente, de fato, não tem qualquer obrigação ou dever de colaborar na investigação do fato. Trata-se, ainda, de típico direito fundamental de primeira geração, de feição negativa e ligado à liberdade, impondo abstenção do Estado.

Existe uma leitura isolada e pontual do art. $5^{\circ}$, LVII, da CF, que leva à conclusão equivocada sobre a impossibilidade da prisão antes do trânsito em julgado da sentença penal condenatória. No limite desse entendimento, as prisões eminentemente cautelares, tais como a temporária (Lei no. 7.960/89) e a preventiva (art. 311 do CPP) restariam inviabilizadas.

\footnotetext{
${ }^{21}$ ALVES JR., Luís Carlos Martins. Constituição, Política \& Retórica. Brasília: Uniceub, 2014. p. 114.

22 BRASIL, Supremo Tribunal Federal, hábeas-córpus no. HC 84078, Relator(a): Min. EROS GRAU, Tribunal Pleno, julgado em 05/02/2009. Voto do Ministro Cesar Peluso. Disponível em: <http://redir.stf.jus.br/paginadorpub/paginador.jsp?docTP=AC\&docID=608531>. Acesso em: 14.09.16.

${ }^{23}$ NUCCI, Guilherme de Souza. Código de processo penal comentado. $5^{\mathrm{a}}$. ed. São Paulo: Ed. Revista dos Tribunais, 2006. p. 53.
} 
Todavia, demonstrar-se-á, mais adiante, que uma interpretação sistemática do ordenamento jurídico revela esse equívoco e conduz à conclusão diversa.

\subsection{Segurança pública: instituto a ser observado em todo o processo criminal}

A segurança constitui direito fundamental individual (art. $5^{\circ}$, caput, da CF). Entendida como direito de primeira geração - cunho negativo -, ela exige do Estado uma abstenção para não turbar a liberdade de cada indivíduo. Por tal razão, exemplificativamente, é defeso ao Judiciário de decretar a prisão preventiva de um sujeito se inexiste o fumus comissi delicti (art. 312, in fine, do CPP).

Além disso, a segurança pública consiste em direito fundamental coletivo (art. $6^{\circ}$, caput, da CF). Havida como direito de segunda geração - cunho positivo -, ela exige dos seus destinatários que empreendam ações positivas para garantir a segurança de todos. Aqui, já se pode iniciar a materialização de um verdadeiro dever de o Poder Judiciário também primar pela garantia da segurança pública.

Em continuação, a segurança pública traduz objetivo fundamental da República Federativa do Brasil (art. $3^{\circ}$, I e IV, da CF). Pela posição topográfica desse art. $3^{\circ}$, que vem logo depois de a Constituição Federal afirmar que "[s]ão poderes da União, independentes e harmônicos entre si, o Legislativo, o Executivo e o Judiciário" (art. $2^{\circ}$ da CF), percebe-se que o Judiciário, por ser um dos Poderes integrantes da República, está plenamente vinculado aos objetivos de construir uma sociedade livre e justa bem como de promover o bem de todos.

A essa altura, já é possível a cogitação acerca de um princípio - no sentido vulgar, ou seja, como um valor ideal a ser perseguido pelos destinatários da Constituição Federal - de segurança pública.

Lado outro, a segurança, estando prevista no preâmbulo da Constituição Federal, deve ser vista como elemento de interpretação e de integração. Segundo Alexandre de Moraes, o preâmbulo não é juridicamente irrelevante, porquanto deve ser observado como elemento de interpretação e integração dos diversos artigos que lhe seguem, por traçar as diretrizes políticas, filosóficas e ideológicas da Constituição, sendo, portanto, uma de suas linhas mestras interpretativas $^{24}$. Em consequência, toda e qualquer interpretação das disposições constitucionais e infraconstitucionais, incluindo a presunção de não-culpabilidade, deve observar a segurança.

No sistema penal pátrio, a segurança tem um viés preventivo, notadamente exercido pela Polícia Militar (e pela Polícia Federal, no âmbito da União), e um viés repressivo. Este é desempenhado pelos três Poderes. Pelo Poder Executivo, na figura da polícia civil, a quem compete investigar as condutas criminosas.

Pelo Poder Legislativo, mediante a edição de leis penais incriminadoras que se destinam a resguardar as violações mais graves aos direitos fundamentais. Destacam-se aqui os mandados constitucionais de criminalização ${ }^{25}$, ou seja, aquelas hipóteses sobre as quais o próprio constituinte originário, a título de direito fundamental, determinou a respectiva criminalização e/ou um tratamento penal mais gravoso, a exemplo dos crimes de tortura e de racismo bem como o tratamento mais severo para crimes considerados hediondos e afins. Igualmente, acentua-se

\footnotetext{
${ }^{24}$ MORAES, Alexandre de. Direito Constitucional. 20a ed. São Paulo: Ed. Atlas, 2006. p. 15.

25 "Mandados expressos de criminalização são disposições constitucionais que impõem a criminalização de certas ações. Não por acaso, esses mandados vêm expressos no título de garantias fundamentais da Constituição Federal, o que permite a conclusão de que a criminalização de certas de certas condutas pelo legislador infraconstitucional representa um direito fundamental coletivo." (FRISCHEISEN, Luiz Cristina Fonseca. GARCIA, Mônica Nicida. GUSMAN, Fábio. Execução provisória da pena. Um contraponto à decisão do Supremo Tribunal Federal no Habeas Corpus 84.078. p. 494 In: CALABRICH, Bruno. FISCHER, Douglas. PELELLA, Eduardo (org.). Garantismo penal integral: questões penais e processuais, criminalidade moderna e aplicação do modelo garantista no Brasil. $3^{\mathrm{a}}$ ed. São Paulo: Ed. Atlas, 2015.
} 
aqui o caráter fragmentário do Direito Penal: "dentre a multidão de fatos ilícitos possíveis, somente alguns - os mais graves - são alcançados pelas malhas do ordenamento penal"26.

Pelo Poder Judiciário, a segurança também deve ser desempenhada, pois ele integra o Estado, a quem a Constituição incumbiu da proteção dos direitos dos indivíduos. Além disso, o julgamento do processo criminal e a execução da sanção estão ontologicamente relacionados à pena criminal, que tem a função, inclusive constitucional, de defender os direitos fundamentais ${ }^{27}$. Como é o Poder Judiciário quem detém o monopólio na realização dos julgamentos e na determinação da execução penal, ele é corresponsável pela garantia da segurança pública. Acertadamente, então, o "dever de garantir a segurança está, além de evitar condutas criminosas que atinjam direitos fundamentais de terceiros, também na devida apuração (com respeito aos direitos dos investigados ou processados) do ato ilícito e, em sendo o caso, na punição do responsável $^{28}$. Exatamente por isso, "resta induvidosa a existência do direito da sociedadecoletividade ao acesso à efetiva justiça penal (eficientes investigação administrativa e persecução judicial dos delitos perpetrados no seio social)" 29 .

Tecidas tais considerações, sublinha-se a necessidade de uma interpretação sistemática da legislação constitucional aplicável ao caso.

\section{EXECUÇÃO PROVISÓRIA DA PENA: RESULTADO DA HARMONIZAÇÃO DA PRESUNÇÃ̃O DE INOCÊNCIA COM A SEGURANÇA PÚBLICA}

A harmonização da presunção de inocência com a segurança pública é uma das tendências do direito processual penal contemporâneo, que busca o equilíbrio entre assegurar ao acusado a aplicação dos seus direitos fundamentais e dotar os sistemas persecutórios de maior eficiência para fins da segurança social. Nesse ponto, os direitos fundamentais da liberdade e da segurança conferem aos indivíduos o direito a que o Estado atue positivamente para estruturar órgãos e criar procedimentos que, concomitantemente, lhes deem segurança e lhes garantam a liberdade. $^{30}$

Para a busca desse equilíbrio, são necessárias a identificação e análise dos fatores e das ferramentas envolvidos no procedimento que buscará a realização ótima do sopesamento desses dois princípios.

\subsection{Definição da culpa é anterior ao julgamento dos recursos excepcionais}

Os recursos excepcionais, no âmbito criminal, desafiam apenas a legislação abstrata, nos termos dos arts. 102, III, e 105, III, ambos da CF, o que demonstra significativa limitação nas suas hipóteses de cabimento. Por conseguinte, porque não é permitida a discussão sobre fatos - e

\footnotetext{
${ }^{26}$ TOLEDO, Francisco de Assis. Princípios básicos de direito penal. $5^{\text {a }}$ ed. São Paulo: Ed. Saraiva, 1994. p. 14-15.

${ }^{27}$ É o que observa PULIDO aos descrever os direitos fundamentais na sua faceta de "direitos de proteção": "[...] a lei penal aparece como medida que o Estado adota para proteger os direitos fundamentais e os demais bens constitucionais" (PULIDO, Carlos Bernal. O direito dos direitos: escritos sobre a aplicação dos direitos fundamentais. Tradução: Thomas da Rosa de Bustamante. São Paulo: Ed. Marcial Pons, 2013. p. 111).

${ }^{28}$ FISCHER, Douglas. Garantismo pena integral (e não o garantismo hiperbólico monocular) e o princípio da proporcionalidade: breves anotações da compreensão e aproximação dos seus ideais. Revista de Doutrina da $4^{\mathrm{a}}$ Região, Porto Alegre, $\mathrm{n}^{\mathrm{o}}$. 28, mar. 2009. p. 4. Disponível em: <http://www.revistadoutrina.trf4.jus.br/index/htm?http://www.revistadoutrina.trf4.jus.br/artigos/edicao028/douglas_f ischer.html>. Acesso em: 04 ago. 2016.

${ }^{29}$ LIMA, Márcio Barra. A colaboração premiada como instrumento constitucionalmente legítimo de auxílio à atividade estatal de persecução criminal. p. 318. In: CALABRICH, Bruno. FISCHER, Douglas. PELELLA, Eduardo (org.). Garantismo penal integral: questões penais e processuais, criminalidade moderna e aplicação do modelo garantista no Brasil. $3^{\mathrm{a}}$ ed. São Paulo: Ed. Atlas, 2015.

${ }^{30}$ FERNANDES, Antonio Scarance. O equilíbrio entre a eficiência e o garantismo e o crime organizado. Revista Brasileira de Ciências Criminais, v. 70, p. 231 e 233, 2008.
}

Revista de Direito Brasileira | São Paulo, SP | v. 18 | n. 7 | p. 242 - 262 | Set./Dez. 2017 
a culpabilidade do réu constitui matéria eminentemente fática -, é vedada a discussão sobre a culpabilidade do âmbito desses dois recursos. Esta é a posição consolidada no âmbito do STF, exposta no Agravo de Instrumento $\mathrm{n}^{\circ} .601 .833^{31}$.

Ademais, a afronta à lei, nesses dois recursos, deve ser direta, e não oblíqua. O STF tem jurisprudência consolidada no sentido de que a violação à lei não pode ser reflexa (ARE $\mathrm{n}^{\circ}$. 969.273/SP ${ }^{32}$ e ARE no. 938.544/PE ${ }^{33}$ ).

Além de não produzir provas, já que os recursos extraordinário e especial não se prestam à discussão de fatos, eles, igualmente, não se destinam ao reexame de provas, consoante o verbete $\mathrm{n}^{\text {o }} .279$ da Súmula do STF ("Para simples reexame de prova não cabe recurso extraordinário.") e o verbete no. 7 da Súmula do STJ (“A pretensão de simples reexame de prova não enseja recurso especial."').

Por outro lado, justamente em razão do desenho e da função institucionais do STF, a Constituição Federal exige, como requisito de admissibilidade do recurso extraordinário, a repercussão geral (art. 102, $\S 3^{\circ}$, da CF). Atualmente, a repercussão geral está definida no art. $1035, \S 1^{\circ}$, do CPC, cuja redação segue: " $§ 1^{\circ}$ Para efeito de repercussão geral, será considerada a existência ou não de questões relevantes do ponto de vista econômico, político, social ou jurídico que ultrapassem os interesses subjetivos do processo" (sem grifos no original). Exatamente por isso, o Ministro Edson Fachin afirmou que o STF e o STJ não foram concebidos, na estrutura recursal prevista nos arts. 102 e $105 \mathrm{da} C F$, parar revisar "injustiças do caso concreto",34.

Por conseguinte, como a tese sustentada no recurso extraordinário deve, necessariamente, ultrapassar os interesses subjetivos do processo - e a culpabilidade do réu recorrente é, evidentemente, questão subjetiva -, o recurso extraordinário cujo tema verse sobre a culpabilidade não tem cabimento.

Demonstrado que os recursos extraordinário e especial não admitem a discussão sobre a culpabilidade do réu, impõe-se, nesses casos, um exame sobre a formação da coisa julgada. Inicialmente desenvolvida pelo Ministro Néri da Silveira, no julgamento do $\mathrm{HC}^{\circ}$. 68726, a ideia da formação da coisa julgada em capítulos foi aprofundada pelo Ministro Luiz Fux, no

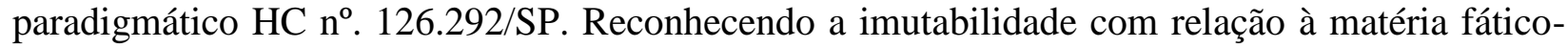
probatória após o julgamento pelas instâncias ordinárias, já que, mediante os recursos extraordinário e especial, se devolvem apenas questões constitucionais e federais, ocorre a formação da coisa julgada quanto ao capítulo atinente à culpabilidade do réu ${ }^{35}$. Estaria autorizada, assim, a execução provisória da pena privativa de liberdade.

\footnotetext{
31 “A via recursal eleita não se presta ao reconhecimento de culpa ou à afirmação de inocência, mas tão-somente ao exame de eventual vulneração de dispositivos constitucionais." (BRASIL, Supremo Tribunal Federal. Agravo de instrumento $n^{\circ}$. 601833 AgR, Relator(a): Min. JOAQUIM BARBOSA, Segunda Turma, julgado em 21/10/2008. Disponível em: <http://redir.stf.jus.br/paginadorpub/paginador.jsp?docTP=AC\&docID=566255>. Acesso em: 14.09.16.)

32 "A alegada ofensa aos incisos I, XXII, XXIX, XXXV, LIV e LV do art. $5^{\circ}$ da CRFB reclama reexame da legislação infraconstitucional aplicável à espécie, impossível na via do recurso extraordinário, por configurar ofensa indireta à Constituição Federal." (BRASIL, Supremo Tribunal Federal. Agravo Regimental no. 969273 AgR, Relator(a): Min. LUIZ FUX, Primeira Turma, julgado em 28/06/2016. Disponível em: <http://redir.stf.jus.br/paginadorpub/paginador.jsp?docTP=TP\&docID=11486599>. Acesso em: 14.09.16.)

33 "A situação de ofensa meramente reflexa ao texto constitucional, quando ocorrente, não basta, só por si, para viabilizar o acesso à via recursal extraordinária." (BRASIL, Supremo Tribunal Federal. Agravo Regimental nº. 938544 ED-AgR, Relator(a): Min. CELSO DE MELLO, Segunda Turma, julgado em 14/06/2016. Disponível em: <http://redir.stf.jus.br/paginadorpub/paginador.jsp?docTP=TP\&docID=11263654>. Acesso em: 14.09.16.)

${ }^{34}$ BRASIL, Supremo Tribunal Federal, HC no. 126292, Relator(a): Min. TEORI ZAVASCKI, Tribunal Pleno, julgado em 17/02/2016. Voto do Ministro Edson Fachin. Disponível em: <http://redir.stf.jus.br/paginadorpub/paginador.jsp?docTP=TP\&docID=10964246>. Acesso em: 14.09.16.

${ }^{35}$ HC 126292, Relator(a): Min. TEORI ZAVASCKI, Tribunal Pleno, julgado em 17/02/2016. Voto do Ministro Luiz Fux. Disponível em: <http://redir.stf.jus.br/paginadorpub/paginador.jsp?docTP=TP\&docID=10964246>. Acesso em: 14.09.16.
} 
De fato, a culpabilidade já foi determinada de forma definitiva. Mesmo eventuais absolvição ou extinção da punibilidade que sobrevenham não estarão fundamentadas no afastamento da culpabilidade, mas em outros motivos, a exemplo da inconstitucionalidade de uma lei ou da prescrição da pretensão punitiva. É exatamente tal situação que permite cogitar a coisa julgada do capítulo alusivo à culpabilidade.

Eis a constatação: a culpa é evidenciada, de forma definitiva, embora não represente ainda a procedência da pretensão punitiva, antes do julgamento dos recursos extraordinário e especial. Por conseguinte, uma vez obtida a coisa julgada relacionada à culpabilidade, resta autorizada a execução provisória da pena privativa de liberdade.

\subsection{Existência de meios para combater eventual ilegalidade na execução provisória}

A existência de meios adequados e céleres ao réu para combater eventual ilegalidade na execução provisória da pena privativa de liberdade contribui para a aceitação desta como providência natural e esperada no evolver do processo criminal no qual a culpa do réu já está demonstrada.

O novo Código de Processo Civil, Lei $\mathrm{n}^{\mathrm{o}}$. 13.105/15, contribuiu sobremaneira nesse aspecto. Ao revogar os artigos 26 a 29 da Lei $n^{\circ}$. 8.038/90, que diziam respeito aos recursos extraordinário e especial, o NCPC afastou o óbice legal à concessão de efeito suspensivo a esses recursos. $\mathrm{O}$ art. $27, \S 2^{\circ}$, da Lei $\mathrm{n}^{\circ}$. 8.038/90 era expresso ao afirmar que os "recursos extraordinário e especial serão recebidos no efeito devolutivo", verificando-se verdadeira omissão eloquente quanto à atribuição do efeito suspensivo. Inclusive, a ausência de previsão a respeito do efeito suspensivo desses recursos constituía um dos principais argumentos da jurisprudência favorável à execução provisória da pena privativa de liberdade.

Além de revogar os arts. 26 a 29 da Lei no $.8 .038 / 90$, os quais, ostentando caráter de lei geral, regulamentavam os recursos extraordinário e especial, o novo NCPC passou a disciplinálos integralmente (Seção II do Capítulo VI do Título II - arts. 1029 a 1041). No art. 1029, §5º ele é expresso quanto à possibilidade da atribuição de efeito suspensivo ao recurso, providência que, nos termos do seu art. 995, parágrafo único, impedirá que a decisão recorrida produza os seus efeitos, quando houver risco de dano grave, de difícil ou impossível reparação, e ficar demonstrada a probabilidade de provimento do recurso.

Aqui, impende observar que o NCPC, o qual regulamenta exaustivamente os recursos em questão, tem aplicação analógica em relação ao CPP, conforme o art. $3^{\circ}$ do CPP. Já o art. 637 do CPP, que proíbe a atribuição do efeito suspensivo ao recurso extraordinário, está assaz enfraquecido após a revogação dos arts. 632 a 636, ambos do CPP, pois constitui o único artigo que trata sobre recurso extraordinário, afora o art. 638 do CPP, que simplesmente se limita a determinar a aplicação do Regimento Interno do STF ao recurso extraordinário.

Nessa linha, sustenta-se a revogação tácita do art. 637 do CPP, pois o NCPC regulamentou integralmente a matéria. Ensina BOBBIO que uma norma deixa de ser válida quando uma norma sucessiva regula a mesma matéria ${ }^{36}$. E, mesmo que se entenda que o critério da especialidade (lex specialis derogat generali) prevalece sobre o critério cronológico (lex posterior derogat legi priori), não há sentido em sustentar-se a vigência do art. 637 do CPP, já que ele, como registrado acima, passou a ser praticamente o único artigo do CPP que diz algo sobre o recurso extraordinário. Foi nítida a intenção do NCPC de regular por completo os recursos excepcionais.

\footnotetext{
${ }^{36}$ Quanto ao estudo da norma, BOBBIO ensina que é necessário “averiguar se não foi ab-rogada, já que uma norma pode ter sido válida, no sentido de que foi emanada de um poder autorizado para isto, mas não quer dizer que ainda $o$ seja, o que acontece quando uma outra norma sucessiva no tempo a tenha expressamente ab-rogado ou tenha regulado a mesma matéria" (BOBBIO, Norberto. Teoria da norma jurídica. Tradução: Fernando Pavan Baptista e Ariani Bueno Sudatti. SP: EDIPRO, $3^{\mathrm{a}}$ ed. 2005. p. 47).
} 
Inexiste, assim, qualquer proibição ex lege de atribuição de efeito suspensivo aos recursos extraordinário e especial. Presentes, portanto, os requisitos cumulativos "risco de dano grave, de difícil ou impossível reparação" e "ficar demonstrada a probabilidade de provimento do recurso", bastará a concessão de efeito suspensivo ao recurso para impedir a execução provisória da pena privativa de liberdade.

Há também outras ferramentas céleres e adequadas para o combate à execução provisória da pena eventualmente ilegal. Se o Tribunal de Justiça ou o Tribunal Regional Federal negar o efeito suspensivo, na hipótese do art. 1029, § 5, III, do NCPC, além de caber a interposição de recurso ou a impetração de hábeas-córpus contra essa decisão, o próprio STJ ou STF poderá atribuir o efeito suspensivo mediante a concessão de ofício de hábeas-córpus. Já na hipótese do art. 1029, § 5 , I e II, do NCPC, se o STJ ou o STF denegar o efeito suspensivo, cabe a impetração de hábeas-córpus ou a interposição de recurso contra tal decisão.

O hábeas-córpus, ademais, tem vantagens sobre os próprios recursos extraordinário e especial para o fim de questionar eventual ilegalidade na execução provisória, pois, ao contrário deles: a) é julgado de forma célere, independentemente de inclusão em pauta ${ }^{37}$; b) havendo prova pré-constituída, não se sujeita à limitação temática dos arts. 102, III, e 105, III, ambos da CF; c) pode revalorar juridicamente o fato concreto $^{38}$, o que descortina o nítido caráter subjetivo e pessoal da impetração; e d) desafia a violação de norma infraconstitucional e, portanto, a ofensa reflexa à Constituição, desde que envolva questão de direito (ex.: incidência, no caso concreto, da atenuante da confissão espontânea) ${ }^{39}$.

A título de registro, pondera-se que, a partir da vigência do Novo Código de Processo Civil, o réu carece de interesse de agir - sob os prismas da adequação e da utilidade - quanto ao ajuizamento de medida cautelar para agregar efeito suspensivo aos recursos extraordinário e especial.

Dessa forma, é certo que o réu dispõe de ferramentas céleres e eficazes para obviar eventual execução provisória da pena privativa de liberdade que seja ilegal. Essa constatação é essencial para a compreensão do motivo por que a execução provisória da pena privativa de liberdade tem cabimento.

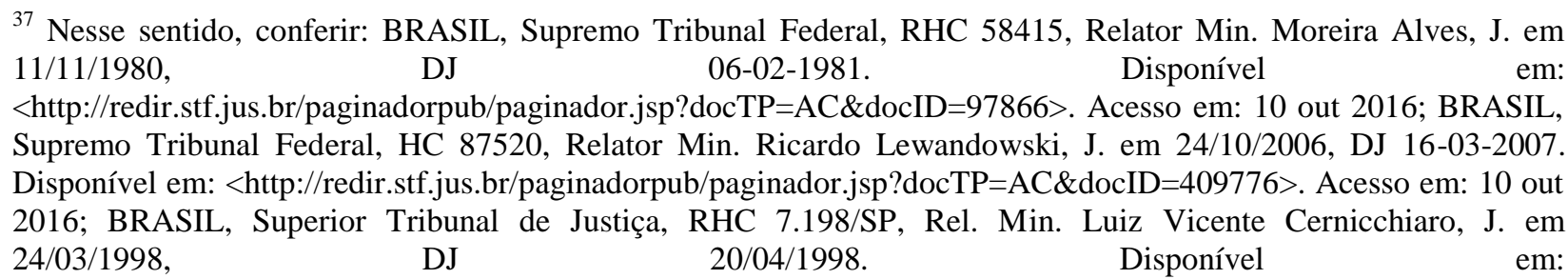
<https://ww2.stj.jus.br/processo/ita/listarAcordaos?classe=\&num_processo=\&num_registro=199800023992\&dt_pub licacao=20/04/1998>. Acesso em: 10 out 2016 .

38 “A valoração jurídica do fato distingue-se da aferição do mesmo, por isso que o exame da presente questão não se situa no âmbito do revolvimento do conjunto fático-probatório, mas importa em mera revaloração dos fatos postos nas instâncias inferiores, o que viabiliza o conhecimento do habeas corpus." (BRASIL, Supremo Tribunal Federal. HC ․ 101698, Relator(a): Min. LUIZ FUX, Primeira Turma, J. em 18/10/2011. Disponível em: < http://redir.stf.jus.br/paginadorpub/paginador.jsp?docTP=TP\&docID=1595332>. Acesso em: 14.09.16).

39 BRASIL, Supremo Tribunal Federal. Recurso ordinário em habeas corpus $\mathrm{n}^{\circ}$. 88862, Relator(a): Min. SEPÚlVEDA PERTENCE, Primeira Turma, julgado em 08/08/2006. Disponível em: < http://redir.stf.jus.br/paginadorpub/paginador.jsp?docTP=AC\&docID=383625>. Acesso em: 14.09.16. No mesmo sentido, admitindo o cabimento do hábeas-córpus para questão de direito infraconstitucional, conferir: BRASIL, Supremo Tribunal Federal, HC 83302, Relator(a): Min. SEPÚLVEDA PERTENCE, Primeira Turma, julgado em 09/03/2004. Disponível em: <http://redir.stf.jus.br/paginadorpub/paginador.jsp?docTP=AC\&docID=79316>. Acesso em: 14.09.16; BRASIL, Supremo Tribunal Federal, HC 77858, Relator(a): Min. MAURÍCIO CORRÊA, Segunda Turma, julgado em 01/12/1998. Disponível em: 〈http://redir.stf.jus.br/paginadorpub/paginador.jsp?docTP=AC\&docID=77600>. Acesso em: 14.09.16.

Revista de Direito Brasileira | São Paulo, SP | v. 18 | n. 7 | p. 242 - 262 |Set./Dez. 2017 


\subsection{A interpretação constitucional direcionada à realização da segurança pública}

$\mathrm{Na}$ interpretação de qualquer ato normativo, desde um dispositivo constitucional até um simples artigo de uma resolução, por exemplo, o intérprete confere sentido ao texto escrito. Para tanto, ele conta com diversas ferramentas hermenêuticas.

\subsubsection{Inexistência de valor absoluto nos princípios: seu caráter prima facie}

Em se tratando de princípios, a primeira ferramenta a ser observada consiste no seu caráter prima facie. "Princípios exigem que algo seja realizado na maior medida possível dentro das possibilidades jurídicas e fáticas existentes. Nesse sentido, eles não contêm um mandamento definitivo, mas apenas prima facie ${ }^{, 40}$.

Justamente em função dessa característica, os princípios são mandamentos de otimização, "que são caracterizados por poderem ser satisfeitos em graus variados e pelo fato de que a medida devida da sua satisfação não depende somente das possibilidades fáticas, mas também das possibilidades jurídicas" ${ }^{31}$. Consequência: nenhum princípio tem valor absoluto, já que, segundo as possibilidades fáticas e jurídicas, ele apresenta um grau de satisfação variável. Daí logo se percebe, com o devido respeito, o equívoco hermenêutico do Ministro Celso de Mello ao, no seu voto proferido no $\mathrm{HC} \mathrm{n}^{\circ}$. 84.078-7/MG (reproduzido no seu voto vencido no HC $\mathrm{n}^{\circ}$. 126.292/SP), ter afirmado que a presunção de inocência "não se esvazia progressivamente, à medida em que [sic] se sucedem os graus de jurisdição". Prosseguindo, "[i]sso significa que, mesmo que confirmada a condenação penal por Tribunal de segunda instância, ainda assim subsistirá, em favor do sentenciado, esse direito fundamental, que só deixará de prevalecer, repita-se, com o trânsito em julgado da sentença penal condenatória"42. Com efeito, esse entendimento esposado pelo Ministro erige a presunção de não-culpabilidade em verdadeiro princípio absoluto. Diversamente, no $\mathrm{HC}^{\circ}{ }^{\circ}$. 129.292/SP, os Ministros Teori Zavascki, Edson Fachin, Luís Barroso e Gilmar Mendes, reconhecendo o caráter de princípio da presunção de nãoculpabilidade e a consequente variabilidade na sua satisfação, fundamentaram, com acerto, que, à medida que o processo avança e se demonstra a culpabilidade do réu, sua presunção de nãoculpabilidade é relativizada ${ }^{43}$.

\subsubsection{A interpretação sistemática visa à unidade da Constituição Federal}

Em outra linha, o intérprete deve, sempre, valer-se de uma interpretação sistemática da norma. Nenhuma norma deve ser interpretada isoladamente, como se não estivesse inserida num contexto normativo maior, que lhe dá sentido e suporte. Afinal, "as normas jurídicas nunca existem isoladamente, mas sempre em um contexto de normas com relações particulares entre

\footnotetext{
${ }^{40}$ ALEXY, Robert. Teoria dos Direitos Fundamentais. Tradução: Virgílio Afonso da Silva. $2^{\mathrm{a}}$ ed. Ed. Malheiros, 2015. p. 103-104.

${ }^{4}$ ALEXY, Robert. Teoria dos Direitos Fundamentais. Tradução: Virgílio Afonso da Silva. $2^{\mathrm{a}}$ ed. Ed. Malheiros, 2015. p. 90.

${ }^{42}$ BRASIL, Supremo Tribunal Federal, hábeas-córpus nº. HC 84078, Relator(a): Min. EROS GRAU, Tribunal Pleno, julgado em 05/02/2009. Voto do Ministro Eros Roberto Grau. Disponível em: <http://redir.stf.jus.br/paginadorpub/paginador.jsp?docTP=AC\&docID=608531>. Acesso em: 14.09.16.

${ }^{43} \mathrm{O}$ Ministro Teori Zavascki foi enfático na seguinte passagem: “(...) tendo havido, em segundo grau, um juízo de incriminação do acusado, fundado em fatos e provas insuscetíveis de reexame pela instância extraordinária, parece inteiramente justificável a relativização e até mesmo a própria inversão para o caso concreto, do princípio da presunção de inocência até então observado". (BRASIL, Supremo Tribunal Federal, hábeas-córpus n. HC 126292, Relator(a): Min. TEORI ZAVASCKI, Tribunal Pleno, julgado em 17/02/2016. Voto do Ministro Teori Zavascki. Disponível em: <http://redir.stf.jus.br/paginadorpub/paginador.jsp?docTP=TP\&docID=10964246>. Acesso em: 14.09.16.)
} 
si"44. Tampouco pode haver interpretação que não observe, por exemplo, a segurança enquanto parâmetro de integração e interpretação e objetivo fundamental da República. Portanto, o órgão julgador deve evitar interpretações que considerem apenas uma norma, ignorando a relação dela com as demais, sob pena de esvaziar estas de sentido quando confrontadas com aquela.

Exatamente por isso, o ex-Ministro do STF Eros Grau, academicamente, ensina que: “A interpretação do direito é interpretação do direito, no seu todo, não de textos isolados, desprendidos do direito. Não se interpreta o direito em tiras, aos pedaços". 45

Logo, o princípio da presunção de não-culpabilidade, como qualquer outro, não pode ser analisado "em tira", "ao pedaço", como se não estivesse inserido num contexto o qual, ao lado da proteção do direito individual de cada pessoa, determina que o Estado promova a segurança pública. De fato, o $\mathrm{HC} \mathrm{n}^{\circ}$. 84.078-7/MG e os demais julgados que seguiram a sua linha fizeram uma leitura "em tira" do princípio sob comento quando alçaram a presunção de não-culpabilidade a princípio absoluto, invariável, a despeito do evolver do processo criminal.

Por outro lado, a interpretação sistemática, logicamente, conduz ao princípio da unidade da Constituição: "a interpretação constitucional deve ser realizada de maneira a evitar contradições entre suas normas" ${ }^{\natural 6}$. Assim, se verificada alguma colisão entre princípios previstos pela Constituição, o intérprete deve alcançar uma solução que os compatibilize, ao mesmo tempo em que busque a "realização máxima dos valores que se imbricam" (princípio da concordância prática). Nessa operação, ainda, a preponderância de um princípio em relação ao outro não pode levar ao esvaziamento completo deste (princípio da proteção no núcleo essencial). De fato, a "realização de uma regra ou princípio constitucional não pode conduzir à restrição a um direito fundamental que lhe retire um mínimo de eficácia" 48 .

De logo, já se observa que o enaltecimento da presunção de inocência como um princípio absoluto, a impedir a prisão do sujeito passivo até o trânsito em julgado da sentença condenatória, atinge fatalmente o núcleo essencial da segurança pública, a qual exige a prisão do agente após a demonstração da sua culpa.

\subsubsection{A vinculação do Poder Judiciário à realização da segurança pública}

Aprofunda-se, agora, a vinculação constitucional do Judiciário à realização e à garantia da segurança pública, tópico já analisado superficialmente no item 2.2 acima.

Discorrendo sobre os direitos fundamentais, Georg Jellinik desenvolveu a teoria dos status. Ao lado do status passivo, do negativo e do ativo, há o status positivo, aquele relacionado ao direito de o indivíduo exigir, em face do Estado, ações estatais. ${ }^{49}$

Com base no status positivo acima aludido, é possível exigir do Estado, mais especificamente do Poder Judiciário, o emprego de ações que privilegiem a segurança pública. No processo penal, que é público, há plena legitimidade do Ministério Público para requerer tal proteção do direito fundamental social à segurança. Não se pode olvidar que, no processo penal, o Estado sempre é vítima diante da violação da ordem jurídica, o que implica uma dimensão objetiva desse tipo de processo, ao lado da dimensão subjetiva relacionada à vítima e ao próprio

\footnotetext{
${ }^{44}$ BOBBIO, Norberto. Teoria do ordenamento jurídico. Tradução: Maria Celeste C. J. Santos. Brasília: UNB, 10ª Ed., 1999. p. 19

${ }^{45}$ GRAU, Eros Roberto. Ensaio e discurso sobre a interpretação/aplicação do direito. $4^{\mathrm{a}}$ ed. Ed. Malheiros, $2006 . \mathrm{p}$. 44.

${ }^{46}$ MORAES, Alexandre de. Direito Constitucional. 20a ed. São Paulo: Ed. Atlas, 2006. p. 15. p. 10.

47 ÁVILA, Humberto. Teoria dos Princípios da definição à aplicação dos princípios jurídicos. $4^{\mathrm{a}}$ Ed. Ed. Malheiros, 2004. p. 96.

48 ÁVILA, Humberto. Teoria dos Princípios da definição à aplicação dos princípios jurídicos. $4^{\mathrm{a}}$ Ed. Ed. Malheiros, 2004. p. 97.

49 ALEXY, Robert. Teoria dos Direitos Fundamentais. Tradução: Virgílio Afonso da Silva. 2a ed. Ed. Malheiros, 2015. p. 254-275.
} 
réu. Justamente em razão dessa dimensão objetiva, o juízo deve pautar suas decisões também pela garantia da segurança da sociedade e do próprio Estado de Direito que foi violada pela prática do crime. Nessa linha, o juízo deve, em obediência à Constituição Federal, determinar o início provisório do cumprimento da pena privativa de liberdade ao observar que a culpabilidade já foi estabelecida e não comporta mais discussão, porquanto, além de os recursos extraordinário e especial discutirem apenas legislação abstrata, a ampla defesa ao réu continua garantida, visto que este dispõe de meios eficazes para combater eventual execução provisória ilegal da pena.

Por outro viés, a perspectiva objetiva dos direitos fundamentais abordada por Sarlet justifica restrições aos direitos subjetivos individuais, tais como a presunção de nãoculpabilidade, em nome do interesse social. Segundo Sarlet:

(...) a perspectiva objetiva dos direitos fundamentais constitui função axiologicamente vinculada, demonstrando que o exercício dos direitos subjetivos individuais está condicionado, de certa forma, ao seu reconhecimento pela comunidade na qual se encontra inserido e da qual não pode ser dissociado, podendo falar-se, neste contexto, de uma responsabilidade comunitária dos indivíduos. É neste sentido que se justifica a afirmação de que a perspectiva objetiva dos direitos fundamentais não só legitima restrições aos direitos subjetivos individuais com base no interesse comunitário prevalente, mas também e de certa forma, que contribui para a limitação do conteúdo e do alcance dos direitos fundamentais, ainda que deva sempre ser preservado o núcleo essencial destes (...). ${ }^{50}$

No Brasil, o Poder Judiciário pode, pelo exercício da jurisdição, limitar direitos fundamentais. Ademais, estes apenas podem ser exercidos de acordo com o interesse comunitário prevalente. Então, se o interesse comunitário consiste na segurança pública, o juízo está vinculado pela Constituição Federal, sob a perspectiva objetiva dos direitos fundamentais nela previstos, a privilegiar a segurança púbica em relação à presunção de não-culpabilidade do sujeito ativo cuja culpabilidade já foi demonstrada na instância ordinária e que, portanto, não comporta mais discussão. O núcleo essencial da presunção de inocência resta preservado, pois os demais efeitos da sentença condenatória (arts. 91 e 92 do $\mathrm{CP}$ e art. 15 da CF) não serão executados provisoriamente. Repisa-se, como dito acima, que se resguarda a ampla defesa do réu para combater eventual ilegalidade na execução provisória da pena mediante a atribuição de efeito suspensivo aos recursos excepcionais e a impetração de hábeas-córpus.

Em outra toada, giza-se que a força normativa da Constituição Federal também exige que o Poder Judiciário paute suas decisões pela realização da segurança. De fato, a Constituição tem uma pretensão de eficácia, a qual consiste em imprimir ordem e conformação à realidade. Quando essa pretensão de eficácia é realizada, a Constituição adquire a sua força normativa. Para tanto, ela impõe tarefas aos seus destinatários. E a Constituição justamente adquire força ativa quando essas tarefas são realizadas, quando existe disposição de orientar a própria conduta segundo a ordem nela estabelecida ${ }^{51}$.

Nessa linha, a Constituição Federal impõe, entre outras, duas tarefas ao Poder Judiciário: proteger a liberdade dos indivíduos com a presunção de não-culpabilidade bem como realizar a segurança pública. Nesse caso, "a interpretação tem significado decisivo para a consolidação e preservação da força normativa da Constituição. A interpretação constitucional está submetida ao

\footnotetext{
${ }^{50}$ SARLET, Ingo Wolfgang. Constituição e proporcionalidade: o direito penal e os direitos fundamentais entre proibição de excesso e de insuficiência. p. 17-18. Disponível em: <egoc.ufsc.br/portal/conteúdo/constituição-eproporcionalidade-o-direito-penal-e-os-direitos-fundamentais-entre-proibicao >. Acesso em: 01.08.16.

${ }^{51}$ HESSE, Konrad. A força normativa da constituição. Tradução: Gilmar Ferreira Mendes. Porto Alegre: Sérgio Antônio Fabris Editor, 1991. p. 11-19.
} 
princípio da ótima concretização da norma" ${ }^{\natural 2}$. Observada então a colisão já identificada entre a presunção de não-culpabilidade e a segurança, tendo-se em conta o caráter variável de realização desses princípios, a ótima concretização deles depende das condições fáticas e jurídicas existentes ao momento da operação. Ao sopesar tais condições, como obtemperado pelo Ministro Luiz Fux, o desenvolvimento da força normativa da Constituição está em que a presunção de inocência "cessa [leia-se: relativiza-se] a partir do momento em que se comprova a culpabilidade do agente, máximo em segundo grau de jurisdição, encerrando um julgamento impassível de ser modificado pelos Tribunais Superiores"53.

Assim, a "vontade de Constituição" 54 demanda do Poder Judiciário a execução da pena privativa de liberdade na pendência dos recursos extraordinário e especial recebidos apenas no efeito devolutivo.

\subsection{O enaltecimento conferido pela proporcionalidade, como proibição contra a proteção insuficiente, à segurança pública na execução provisória da pena}

A proporcionalidade consiste em ferramenta pela qual se faz a ponderação entre princípios que colidem entre si. Sua natureza jurídica é de postulado normativo, ou seja, uma "metanorma". Postulados são, para Ávila, "normas estruturantes da aplicação de princípios e regras" regras, principalmente na hipótese de colisão.

A proporcionalidade, teoria decorrente do direito alemão e que se transformou em um dos pilares do Estado de Direito Democrático ${ }^{56}$, pode ser estudada sob o prisma da proibição de excesso (Ußermassverbot), de cunho negativo, vale dizer, uma ferramenta para aferir se a intervenção restritiva por parte do Estado, na esfera do indivíduo, é legítima. Objetiva-se evitar que o Estado intervenha de forma excessiva, desarrazoada, sobre o indivíduo. Para tanto, são analisadas três máximas (ou subprincípios) da proporcionalidade: adequação (o meio promove o fim?); necessidade (dentre os meios disponíveis e igualmente adequados para promover o fim, não há outro meio menos restritivo do(s) direito(s) fundamentais afetados?); e proporcionalidade em sentido estrito (as vantagens trazidas pela promoção do fim correspondem às desvantagens provocadas pela adoção do meio?). ${ }^{57}$

No entanto, cada vez mais ganha importância a utilização da proporcionalidade como instrumento contra a omissão ou contra a ação insuficiente dos poderes estatais. Antes se falava apenas em Ußermassverbot, ou seja, proibição de excesso; já há algum tempo, fala-se também em Untermassverbot, que pode ser traduzido como proibição de insuficiência ${ }^{58}$. Assim, a noção de proporcionalidade não se esgota na categoria da proibição do excesso, pois está vinculada a

\footnotetext{
${ }^{52}$ HESSE, Konrad. A força normativa da constituição. Tradução: Gilmar Ferreira Mendes. Porto Alegre: Sérgio Antônio Fabris Editor, 1991. p. 22.

53 BRASIL, Supremo Tribunal Federal. HC nº. 126.292/SP. Voto do Ministro Luiz Fux. Disponível em: <http://redir.stf.jus.br/paginadorpub/paginador.jsp?docTP=TP\&docID=10964246>. Acesso em: 14.09.16.

${ }^{54}$ HESSE, Konrad. A força normativa da constituição. Tradução: Gilmar Ferreira Mendes. Porto Alegre: Sérgio Antônio Fabris Editor, 1991.

${ }^{55}$ ÁVILA, Humberto. Teoria dos Princípios da definição à aplicação dos princípios jurídicos. $4^{\mathrm{a}} \mathrm{Ed}$. Ed. Malheiros, 2004. p. 90 .

56 SARLET, Ingo Wolfgang. Constituição e proporcionalidade: o direito penal e os direitos fundamentais entre proibição de excesso e de insuficiência. p. 3. Disponível em: <egoc.ufsc.br/portal/conteúdo/constituição-eproporcionalidade-o-direito-penal-e-os-direitos-fundamentais-entre-proibicao>. Acesso em: 01.08.16.

57 ÁVILA, Humberto. Teoria dos Princípios da definição à aplicação dos princípios jurídicos. $4^{\mathrm{a}}$ Ed. Ed. Malheiros, 2004. p. 90.

${ }^{58}$ SILVA, Luís Virgílio Afonso da. O proporcional e o razoável. RT, São Paulo: Revista dos Tribunais, ano 91 , nº 798, abr. 2002. p. 41
}

Revista de Direito Brasileira | São Paulo, SP | v. 18 | n. 7 | p. 242 - 262 |Set./Dez. 2017 
um dever de proteção por parte do Estado, inclusive quanto a agressões contra direitos fundamentais oriundas de terceiros ${ }^{59}$.

Segundo Claus-Wilhelm Canaris ${ }^{60}$, a proibição de insuficiência, expressão criada por ele e adotada pelo Tribunal Constitucional Federal alemão, envolve dois níveis sucessivos entre si: o imperativo de tutela (ou dever de proteção) e a proibição de insuficiência propriamente considerada. No primeiro nível - dever de proteção ("se" existe o dever de proteção) -, analisa-se se existe um dever de o Estado proteger determinado direito. No segundo nível - proibição de insuficiência ("como" se realiza o dever de proteção) -, a que se chega apenas em caso de constatação positiva do primeiro, avalia-se se as medidas adotadas para a proteção do direito são suficientes para a sua finalidade. Tais medidas, tendo em vista o seu cunho regulamentador, não são de competência da Constituição, mas da legislação ordinária. É exatamente nesse ponto que desponta, novamente, a vinculação do próprio Poder Judiciário à proibição de insuficiência: a interpretação e a integração do direito, visto este como a legislação, são tarefas atribuídas ao Poder Judiciário, as quais são essenciais para a realização do imperativo de tutela dos direitos fundamentais. Se o juiz não cumprir a sua tarefa, "se verificaria um inconstitucional défice de protecção, e, portanto, uma violação da proibição de insuficiência"61.

A essa quadra, afigura-se essencial compreender, no Brasil, que o dever de garantir a segurança está positivado na Constituição (primeiro nível - imperativo de tutela). Ademais, o legislador ordinário brasileiro se desincumbiu do seu dever de proteção, visto no segundo nível (proibição de insuficiência), ao aprovar legislação que confere a possibilidade de atribuição de efeito suspensivo aos recursos extraordinário e especial. Explica-se: a possibilidade de atribuição desse efeito significa que, nos casos em que ele não for deferido, a execução provisória da pena privativa de liberdade é devida e justificada para os fins de garantia da segurança pública. Essa foi a escolha feita pelo legislador ordinário.

Em seguimento, é a vez de o Poder Judiciário, mediante a interpretação e a integração do direito posto, desincumbir-se da sua tarefa para realizar o imperativo de tutela dos direitos fundamentais. Para tanto, ele se utiliza da proporcionalidade.

Um estudo completo sobre a aplicação dos três subprincípios da proporcionalidade adequação, necessidade e proporcionalidade em sentido estrito - em relação à proibição da insuficiência foi apresentado por PULIDO. Após a analisar a adequação - se a restrição a um direito fundamental promove ou não a finalidade - e a necessidade - qual, entre todas as medidas, é a menos restritivas -, ele conclui quanto à proporcionalidade em sentido estrito:

Uma abstenção legislativa ou uma norma legal que não proteja um direito fundamental de maneira ótima vulnera as exigências do princípio da proporcionalidade em sentido estrito quando o grau de favorecimento do fim legislativo (a não intervenção na liberdade) é inferior ao grau em que não se realiza o direito fundamental de proteção [...] Está proibido que a intensidade em que não se garanta um direito de proteção seja intensa e que a magnitude da não intervenção na liberdade ou em outro direito de defesa seja leve ou média, ou que a intensidade da não proteção seja média e a não intervenção seja leve. ${ }^{62}$

\footnotetext{
${ }^{59}$ SARLET, Ingo Wolfgang. Constituição e Proporcionalidade: o direito penal e os direitos fundamentais entre a proibição de excesso e de insuficiência. p. 3. Disponível em: <egov.ufsc.br/portal/conteúdo/constituição-eproporionalidade-o-direito-penal-e-os-direitos-fundamentais-entre-proibicao > Acesso em: 01.08.16.

${ }^{60}$ CANARIS, Claus-Wilhelm. Direitos Fundamentais e Direito Privado. Tradução: Ingo Wolfgang Sarlet e Paulo Mota Pinto. Ed. Almedina.

${ }^{61}$ CANARIS, Claus-Wilhelm. Direitos Fundamentais e Direito Privado. Tradução: Ingo Wolfgang Sarlet e Paulo Mota Pinto. Ed. Almedina. p. 124.

${ }^{62}$ PULIDO, Carlos Bernal. O direito dos direitos: escritos sobre a aplicação dos direitos fundamentais. Tradução: Thomas da Rosa de Bustamante. São Paulo: Ed. Marcial Pons, 2013. p. 134.
} 
A análise a ser realizada deve considerar a seguinte colisão: de um lado, o valor liberdade representado pela presunção de inocência, a qual, constituindo princípio, comporta gradação segundo as condições fático-jurídicas; de outro lado, a segurança pública, que exige a privação da liberdade, em tempo razoável, do sujeito cuja culpabilidade já foi reconhecida. Como harmonizar os valores envolvidos nessa colisão?

No caso sob análise, o juiz observará que, no tocante à presunção de não-culpabilidade, os princípios do duplo grau de jurisdição, do contraditório e da ampla defesa foram respeitados, como já referido nos itens 1.1.1, 1.1.2 e 1.1.3 supra. Já no atinente à segurança, o juiz observará a necessidade, além da celeridade processual, da própria efetividade processual, no sentido de o processo criminal chegar a seu termo, dando uma satisfação à sociedade, a qual, em caso de procedência da denúncia criminal, fica reconhecida como covítima do crime praticado pelo réu.

Nessa colisão, é fundamental compreender que a culpabilidade não mais comporta discussão, estando definitivamente assentada. Repisa-se que eventual absolvição ou extinção da punibilidade, nessa fase processual, não decorrerá da negação da culpa. Dessa forma, a presunção de culpabilidade deve sofrer uma variação na sua aplicação, justamente porque depende das condições fático-jurídicas então existentes. E a condição fático-jurídica da impossibilidade de discussão da culpa permite a relativização desse princípio, desde que o seu núcleo seja preservado. É exatamente isto o que ocorre com a execução provisória da pena mediante a denegação do efeito suspensivo aos recursos extraordinário e especial: o réu continua sendo tratado como inocente, pois nenhum dos efeitos da sentença penal condenatória lhe é aplicado, à exceção da pena privativa de liberdade, providência que se justifica para fins da segurança pública vista como ordem pública ${ }^{63}$.

Pela proporcionalidade sob o viés acima apresentado por PULIDO, a execução provisória da pena privativa de liberdade é medida proporcional, ao contrário do enaltecimento absoluto da presunção de não-culpabilidade de forma a exigir o trânsito em julgado da sentença condenatória. Confira-se: caso se exija o trânsito em julgado para fins da execução provisória em relação ao réu cuja culpa já foi demonstrada definitivamente e não comporta mais discussão, o grau de realização da não-intervenção estatal na liberdade do réu é inferior ao grau de realização da segurança pública, para a qual é necessário o desfecho célere e eficaz do processo penal.

Tal interpretação, outrossim, observa a concordância prática e realiza de forma máxima os princípios então tensionados, consideradas as circunstâncias fático-jurídicas: culpa não mais sujeita à discussão e segurança que exige o julgamento célere e o cumprimento da pena. Além disso, demonstrada a sua proporcionalidade, está evidenciado, ipso facto, o respeito ao princípio do devido processo legal (item 1.1.4)

\section{CONCLUSÃO}

O presente trabalho cumpriu seu objetivo ao demonstrar que a execução provisória da pena privativa de liberdade na pendência de recursos extraordinário e/ou especial recebidos sem efeito suspensivo, mais do que justificada, é imposta pela Constituição Federal.

De fato, ela não ofende o princípio da do duplo grau de jurisdição, pois este reclama apenas um julgamento por órgão colegiado. Ela não viola a ampla defesa, visto que a defesa técnica persiste atuando nessa fase. Ela não desrespeita o contraditório, tendo em vista que a

\footnotetext{
${ }^{63}$ Embora não seja objeto deste artigo o estudo acerca da natureza jurídica da prisão decorrente da execução provisória da pena privativa de liberdade, calha conferir destaque à seguinte consideração realizada pelo Ministro Barroso no seu voto exarado no $\mathrm{HC} \mathrm{n}^{\circ}$. 126.292/SP: “o início do cumprimento da pena no momento do esgotamento da jurisdição ordinária impõe-se como uma exigência de ordem pública, em nome da necessária eficácia e credibilidade do Poder Judiciário" (grifos nosso). (BRASIL, Supremo Tribunal Federal, hábeas-córpus nº HC 126292, Relator(a): Min. TEORI ZAVASCKI, Tribunal Pleno, julgado em 17/02/2016. Disponível em: < http://redir.stf.jus.br/paginadorpub/paginador.jsp?docTP=TP\&docID=10964246>. Acesso em: 14.09.16).
}

Revista de Direito Brasileira | São Paulo, SP | v. 18 | n. 7 | p. 242 - 262 |Set./Dez. 2017 
bilateralidade do ato processual se dá mediante a intimação prévia da defesa técnica sobre a decisão de que resulta o mandado de prisão.

A interpretação sistemática do ordenamento jurídico igualmente demonstra o cabimento da execução provisória da pena. O princípio da presunção de inocência não pode ser interpretado isoladamente, ou seja, "em tira"; ele deve ser relacionado às demais normas de forma a conferir unidade à Constituição. Nessa linha, leva-se em conta o caráter prima facie inerente a qualquer princípio que: a) permite a gradação na sua aplicação segundo as condições fático-jurídicas então existentes; e b) evidencia a inexistência de princípio com valor absoluto. Impende observar, outrossim, a vinculação constitucional do Poder Judiciário à realização/garantia da segurança. Nesse quadro, a proporcionalidade vista como proibição de insuficiência privilegia a segurança pública, na fase da execução provisória da pena privativa de liberdade, pois a impossibilidade de discussão adicional a respeito da culpa decorrente do trânsito em julgado desse capítulo da sentença (condição jurídica que deve ser valorada pelo caráter prima facie) justifica a relativização da presunção de não-culpabilidade de modo a permitir o cumprimento da pena. Resta preservado o núcleo essencial da presunção de inocência (demais efeitos da sentença condenatória não são adiantados), tudo com a finalidade da realização do valor perseguido pela segurança pública. Nessa operação, há concordância prática entre os princípios tensionados, cujos objetivos são cumpridos da maneira mais ampla possível, segundo as condições fático-jurídicas então existentes. Ainda, frisa-se que a preservação do núcleo essencial do princípio da presunção de inocência - não-adiantamento dos demais efeitos da condenação - evidencia o respeito a ela pela execução provisória.

Por outro lado, a exigência do trânsito em julgado da sentença penal condenatória para o início do cumprimento da pena privativa de liberdade representa uma contradição à lógica processual penal, como percebido pelo Ministro Menezes de Direito. Soa incoerente admitir a prisão cautelar antes mesmo da sentença condenatória, com base em uma cognição sumária e limitada, mas não admitir a prisão para fins da execução provisória da pena na pendência de recurso extraordinário e/ou especial, momento em que cognição probatória quanto à culpabilidade já foi realizada de forma plena e exauriente ${ }^{64}$.

Por fim, frisa-se que o presente raciocínio quanto à execução provisória da pena privativa de liberdade tem aplicação, mutatis mutandis, em duas outras áreas, as quais, todavia, em razão da limitação temática e espacial deste trabalho, não pode ser aqui aprofundadas. Aludese à execução das penas restritivas de direitos, desde que se observe a necessidade de uma interpretação conforme a Constituição do art. 147 da Lei nº 7.210/84. Aliás, o STF já decidiu nesse sentido, como se observa nos julgados HC 83978/RS ${ }^{65}$ e HC 84336/RS ${ }^{66}$.

Igualmente, a execução provisória da pena privativa de liberdade tem cabimento nas sentenças condenatórias do tribunal do júri. Fundamentalmente, à exceção da apelação fundamentada no art. 593, III, $d$, do CPP (decisão dos jurados manifestamente contrária à prova dos autos, ou seja, aquela decisão que não se ampara em nenhuma vertente probatória dos autos), a culpa não pode mais ser discutida. Diante dessa dificílima possibilidade de revisão da decisão dos jurados, considerando-se também a legitimidade democrática desse tipo de decisão, o cumprimento imediato da pena privativa de liberdade imposta pelo juiz presidente também encontra justificativa. Todavia, repisa-se, esse é assunto para outro trabalho.

\footnotetext{
${ }^{64}$ BRASIL, Supremo Tribunal Federal, hábeas-córpus no. HC 84078, Relator(a): Min. EROS GRAU, Tribunal Pleno, julgado em 05/02/2009. Voto do Ministro Menezes de Direito. Disponível em: $<$ http://redir.stf.jus.br/paginadorpub/paginador.jsp?docTP=AC\&docID=608531>. Acesso em: 14.09.16.

${ }^{65}$ BRASIL. Supremo Tribunal Federal. HC 83978/RS. Relator: Min. Carlos Veloso. J. em 13/04/2004, DJ 28-052004. Disponível em: <http://redir.stf.jus.br/paginadorpub/paginador.jsp?docTP=AC\&docID=384858>. Acesso em: 10 out 2016.

${ }^{66}$ BRASIL. Supremo Tribunal Federal. HC 84336/RS. Relatora: Min. Ellen Gracie. J. em 14/09/2004, DJ 01-102004. Disponível em: <http://redir.stf.jus.br/paginadorpub/paginador.jsp?docTP=AC\&docID=79552>. Acesso em: 10 out 2016.
} 


\section{REFERÊNCIAS BIBLIOGRÁFICAS}

ALEXY, Robert. Teoria dos Direitos Fundamentais. Tradução: Virgílio Afonso da Silva. $2^{\mathrm{a}}$ ed. Ed. Malheiros, 2015.

ALVES JR., Luís Carlos Martins. Constituição, Política \& Retórica. Brasília: Uniceub, 2014.

ÁVILA, Humberto. Teoria dos Princípios da definição à aplicação dos princípios jurídicos. $4^{\mathrm{a}}$ Ed. Ed. Malheiros, 2004.

BARROSO, Luís Roberto. BARCELLOS, Ana Paula. O começo da história. A nova interpretação constitucional e o papel dos princípios no direito brasileiro. O Interesse Público IP. Belo Horizonte, $\mathrm{n}^{\mathrm{o}}$. 19, ano 5 Maio / Junho 2003 Disponível em: <http://www.bidforum.com.br/bid/PDI0006.aspx?pdiCntd=50962>. Acesso em: 04.05.2016.

BOBBIO, Norberto. Teoria da norma jurídica. Tradução: Fernando Pavan Baptista e Ariani Bueno Sudatti. SP: EDIPRO, $3^{\text {a }}$ ed. 2005.

BOBBIO, Norberto. Teoria do ordenamento jurídico. Tradução: Maria Celeste C. J. Santos. Brasília: UNB, 10ª Ed., 1999.

CALABRICH, Bruno. FISCHER, Douglas. PELELLA, Eduardo (org.). Garantismo penal integral: questões penais e processuais, criminalidade moderna e aplicação do modelo garantista no Brasil. $3^{\mathrm{a}}$ ed. São Paulo: Ed. Atlas, 2015.

CANARIS, Claus-Wilhelm. Direitos Fundamentais e Direito Privado. Tradução: Ingo Wolfgang Sarlet e Paulo Mota Pinto. Ed. Almedina.

FERNANDES, Antonio Scarance. O equilíbrio entre a eficiência e o garantismo e o crime organizado. Revista Brasileira de Ciências Criminais, v. 70, p. 231 e 233, 2008.

FISCHER, Douglas. Execução de Pena na Pendência de Recursos Extraordinário e Especial em Face da Interpretação Sistêmica da Constituição. Uma Análise do Princípio da Proporcionalidade: entre a Proibição do Excesso e a Proibição de Proteção Deficiente. In Direito Público. Ano V, nº. 25, jan-fev 2006. p. 07-30.

FISCHER, Douglas. Garantismo pena integral (e não o garantismo hiperbólico monocular) e o princípio da proporcionalidade: breves anotações da compreensão e aproximação dos seus ideais. Revista de Doutrina da $4^{\text {a }}$ Região, Porto Alegre, no. 28, mar. 2009. Disponível em: <http://www.revistadoutrina.trf4.jus.br/index/htm?http://www.revistadoutrina.trf4.jus.br/artigos/e dicao028/douglas_fischer.html>. Acesso em: 04 ago. 2016.

GRAU, Eros Roberto. Ensaio e discurso sobre a interpretação/aplicação do direito. $4^{\mathrm{a}} \mathrm{ed}$. Ed. Malheiros, 2006.

GRINOVER, Ada Pellegrini. GOMES FILHO, Antônio Magalhães. FERNANDES, Antônio Scarance. Recursos no processo penal: teoria geral dos recursos, recursos em espécie, ações de impugnação, reclamação aos tribunais. $6^{\text {a }}$ ed. São Paulo: Ed. RT, 2009. 
HESSE, Konrad. A força normativa da constituição. Tradução: Gilmar Ferreira Mendes. Porto Alegre: Sérgio Antônio Fabris Editor, 1991.

HOUAISS, Antônio. Dicionário Eletrônico 3.0. Versão eletrônica. Ed. Objetiva, 2009.

LOPES JR., Aury. Direito Processual Penal. 9a ed. São Paulo: Saraiva, 2012.

MORAES, Alexandre de. Direito Constitucional. 20ª ed. São Paulo: Ed. Atlas, 2006.

NUCCI, Guilherme de Souza. Código de processo penal comentado. $5^{\mathrm{a}}$. ed. São Paulo: Ed. Revista dos Tribunais, 2006.

OLIVEIRA, Eugênio Pacelli. Curso de Processo Penal. 12 ${ }^{\mathrm{a}}$ ed. Rio de Janeiro: Lumen Iuris, 2009.

OLIVEIRA, Eugênio Pacelli. FISCHER, Douglas. Comentários ao Código de Processo Penal e sua jurisprudência. $4^{\mathrm{a}}$ ed. São Paulo: Ed. Atlas, 2012.

PULIDO, Carlos Bernal. O direito dos direitos: escritos sobre a aplicação dos direitos fundamentais. Tradução: Thomas da Rosa de Bustamante. São Paulo: Ed. Marcial Pons, 2013.

SARLET, Ingo Wolfgang. Constituição e proporcionalidade: o direito penal e os direitos fundamentais entre proibição de excesso e de insuficiência. Disponível em: <egoc.ufsc.br/portal/conteúdo/constituição-e-proporcionalidade-o-direito-penal-e-os-direitosfundamentais-entre-proibicao>. Acesso em: 01.08.16.

SILVA, Luís Virgílio Afonso da. O proporcional e o razoável. RT, São Paulo: Revista dos Tribunais, ano 91, $\mathrm{n}^{\circ} .798$, abr. 2002.

STRECK, Lênio Luiz. A dupla face do princípio da proporcionalidade: da proibição de excesso (Übermassverbot) à proibição de proteção deficiente (Untermassverbot) ou de como não há blindagem contra normas penais inconstitucionais. Revista da Ajuris, ano XXXII, $\mathrm{n}^{\circ} .97$, março de 2005. p.171-202.

TOLEDO, Francisco de Assis. Princípios básicos de direito penal. $5^{\text {a }}$ ed. São Paulo: Ed. Saraiva, 1994. 